DOI: https://doi.org/10.32347/2077-3455.2021.60.67-78

УДК 719

Nourel houda Rezig,

Graduate student

Chair of Architectural basis and Design

Kyiv National University of Construction and Architecture

rehiz_nk@knuba.edu.ua

https://orcid.org/0000-0002-3556-3415

\title{
ANCIENT TRADITIONAL SETTLEMENTS IN ALGERIA: PENTAPOLIS OF M'ZAB VALLEY
}

Abstract: article concerns of the ancient traditional settlements of Algeria. The main attention are payed to the introduction of architecture of M'zab Valley that is a special historical urban phenomenon of Algerian. Article deals with five old historical preserved settlements, so called ksour, that are gathered in the agglomeration of M'zab Valley (so called Pentapolis) in the oasis of Sahara desert. The article is analysing the traditional planning structure and architecture of ksour in urban scale (macro level) pointing special attention to the climate adaptation techniques of building in the severe natural environment of Sahara desert. The Pentapolis of M'zab Valley is unique example of agglomeration where people dwells preserving traditions more than millennium of the years using the same urban infrastructures and buildings. In this point of view, it could be considered like an excellent case for study the harmonization of ancient traditions in the circumstances of modernity by living in the substantiality with environment.

Key words: M'zab Valley; Mozabite Architecture; Pentapolis; Ksour; Traditional settlements; Algeria desert; UNISCO World Heritage.

Introduction to the problem. The problem of the harmonization of traditional settlements with modernity is actual now all over the world. From this point of view the case of traditional settlements of Algeria, particularly the Pentapolis of M'zab Valley is extremely interesting because it is an example of some kind of "time delay", settlements where people are living constantly by using the same architectural objects for about millennium years with no direct connection with other world.

The publications and researches of the problem. From the end of 19th century, many researchers and architects have been interested in the issue of traditional architecture in the M'zab Valley. André Coyne [1], Amat Charles [2], Marcel Morand [3], Marcel Mercier [4], A. M. Goichon [5] and others started to investigate the diversity of M'zab architecture and tradition. Then the researches of this topic were continued by contemporain specialist such as André Ravereau [6-7], 
Manuelle Roche [8], Brahim Benyoucef [9] and others who lighted up different uranic, architectural and cultural aspects of local life. Nevertheless, as for the investigation of the problems of traditional M'zab Valley harmonisation with modernity it is still could be find a lot of "blind points" that we intend to fill up in our future work.

The purpose of the article is to summarize the information about traditional planning structure and architecture of M'zab Valley historical settlements in urban scale by examining their initial stability of living according traditional principles and in the substantiality with environment.

People's Democratic Republic of Algeria and its UNNESCO World heritage sites. Algeria is a country located in North Africa in the middle of the Maghreb region, its capital named Algiers. Algeria is bordered via the Mediterranean Sea in north, Libya in east, Tunisia in northeast, Morocco in the west, Niger in the southeast, and by Western Sahara, Mauritania, Mali in the southwest.

Algeria's area is $2,381,741 \mathrm{~km}$ sq. It is the largest territory in the African Union and the Arab world, with an estimated population of over 44 million. There are 83\% of Arabian population, $17 \%$ of Amazigh. The Europeans are less than 1\%. About $90 \%$ of Algerians live in the northern, coastal plains near the Mediterranean Sea.

The Algerian lands lies mostly between $19^{\circ}$ and $37^{\circ}$ north latitude (a small area is north of $37^{\circ} \mathrm{N}$ and south of $19^{\circ} \mathrm{N}$ ), and $9^{\circ} \mathrm{W}$ and $12^{\circ} \mathrm{E}$ longitudes. Country lands include four types of terrain: the coastal mountainous chain, plains and high plateaus, the mountainous chain of the interior of the country, and the area of mountainous chain in the south [10].

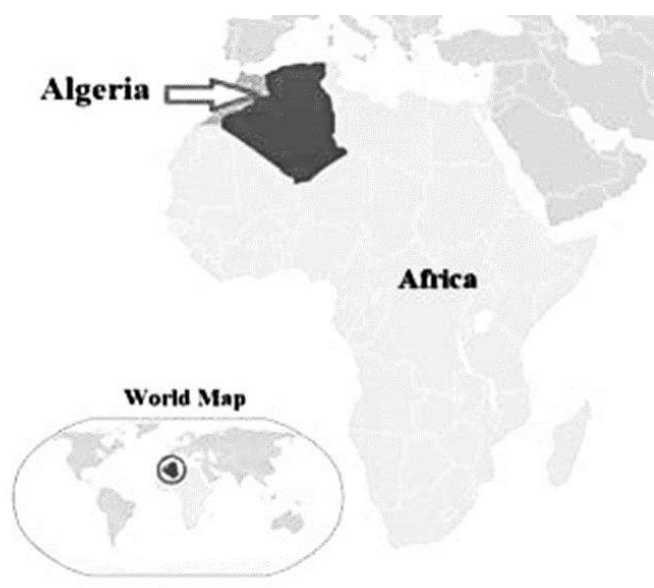

Figure 1: Algeria's location.

(Source: http://www.vidiani.com/algeria-location-map/, modified by Author)

Northern Algeria is situated in agreeable temperate zone, enjoying a mild, Mediterranean climate. The winters are not cold, but the humidity is high and summers are hot, dry along the coast. In eastern part of the country, the climate is drier with cold winters and hot summers on the high plateau, and on the steppes, 
winter temperatures hover are only a few degrees above freezing. In the south of the country, the climate is arid or desert. A prominent feature of the climate in this region is a hot, dust/sand-laden wind sirocco that is especially common in summer.

Algeria's aboriginal population Amazigh has been under foreign Authority for more than the last 3000 years. The Phoenicians, the Romans and Vandals were the most important invaders there. With the advent of the Muslim Arabs in the 7th-8th century to North Africa, Islam's affect came to the Amazigh and they spent a millennium under dominance of Arab dynasties. Until the beginning of the 16th century, Algeria became under safeguard of the Ottoman Sultan of Istanbul, followed by rule of Ottoman beys, aghas, and pashas. This period ended with the beginning of the French colonization in 1830 which led to armed resistance lasting for decades. After 130 years of reign by France, the People's Democratic Republic of Algeria became independent in 1962. The predominant religion in Algeria is Islam, 97\% of the population follows Sunni Islam, and 1.3\% are Ibadis's Muslims from M'zab Valley in the region of Ghardaia. Estimates of Christian and Jewish living in Algeria are about $1 \%$. Arabic and Tamazight now serve as both official and national languages in Algeria. French is the most generally used foreign language, although it has no official status, Algeria is the second-largest francophone country within the world in terms numbers of speakers.

UNESCO is keen to include the most important Heritage sites under its legal protection. The selection depends on ten criteria, six of them for cultural heritage and four for natural heritage. The World Heritage Sites are nominated for having a cultural, historical, scientific, natural importance and must be of "outstanding universal value". Algeria was fortunate to include seven sites classified by UNESCO as World Heritage Sites, shown in figure 2 and the table 1 below [11].

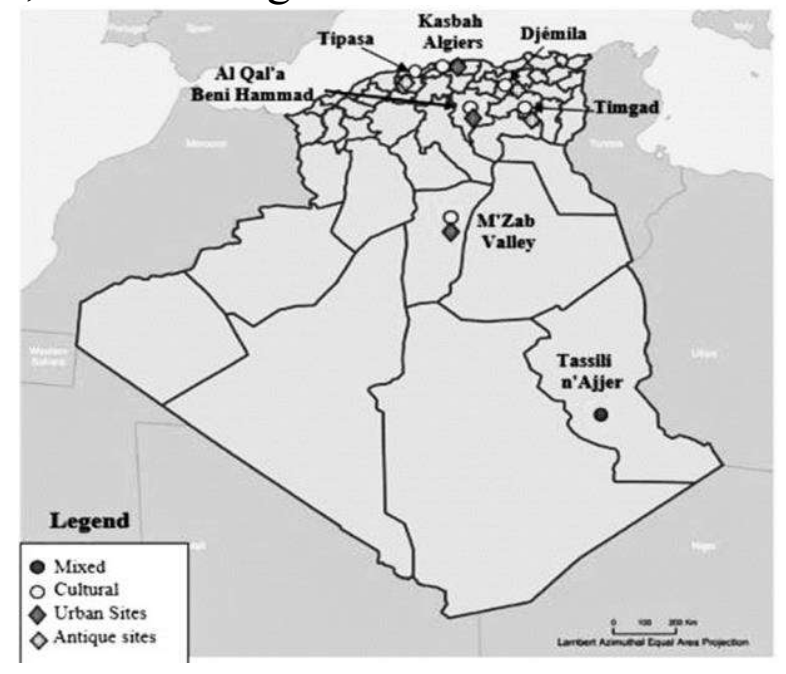

Figure 2: Locations and types of UNESCO World Heritage Sites in Algeria. (Source: Figshare. https://figshare.com/articles/figure/Map of locations of PPRV outbreaks in Algeria since 2010 /4894250/1, modified by Author). 
Table 1. World Heritage Sites in Algeria. (Source: UNESCO official site).

\begin{tabular}{|c|c|c|c|c|c|c|}
\hline Site & Province & Year & Туре & $\begin{array}{c}\text { Area } \\
\text { (ha) }\end{array}$ & $\begin{array}{c}\text { Selection } \\
\text { criteria }\end{array}$ & Description \\
\hline M'zab Valley & Ghardaïa & 1982 & Cultural & 4000 & (ii)(iii)(v) & $\begin{array}{l}\text { Islamic city with five } \\
\text { ksour built along } \\
\text { M'zab Valley. }\end{array}$ \\
\hline $\begin{array}{c}\text { Kasbah of } \\
\text { Algiers }\end{array}$ & Algiers & 1992 & Cultural & 50 & (ii)(v) & $\begin{array}{l}\text { Islamic city on the } \\
\text { Mediterranean coast, } \\
\text { a mixture between } \\
\text { Ottoman architecture } \\
\text { and Maghreb city. }\end{array}$ \\
\hline Djémila & Sétif & 1982 & Cultural & 31 & (iii)(iv) & $\begin{array}{l}\text { Roman town in a } \\
\text { mountainous region, } \\
\text { composed of forum, } \\
\text { temples, and } \\
\text { religious buildings. }\end{array}$ \\
\hline Timgad & Batna & 1982 & Cultural & 91 & (ii)(iii)(iv) & $\begin{array}{l}\text { The ruins of Roman } \\
\text { town existed as a } \\
\text { military colony. }\end{array}$ \\
\hline $\begin{array}{c}\text { Beni } \\
\text { Hammad Fort }\end{array}$ & M'sila & 1980 & Cultural & 150 & (iii) & $\begin{array}{l}\text { The ruins of Muslim } \\
\text { city, the first capital } \\
\text { of the Hammadid } \\
\text { emirs. }\end{array}$ \\
\hline Tipasa & Tipaza & 1982 & Cultural & 52 & (iii)(iv) & $\begin{array}{l}\text { The ruins of Roman } \\
\text { town on the } \\
\text { Mediterranean coast, } \\
\text { military colony }\end{array}$ \\
\hline Tassili n'Ajjer & $\begin{array}{l}\text { Illizi and } \\
\text { Tamanrass }\end{array}$ & 1982 & Mixed & 7200 & $\begin{array}{l}\text { (i) (iii)(vii) } \\
\text { (viii) }\end{array}$ & $\begin{array}{l}\text { Plateau on the desert } \\
\text { contains cave } \\
\text { engravings that } \\
\text { describe the } \\
\text { evolution of human } \\
\text { life, Centuries BC. }\end{array}$ \\
\hline
\end{tabular}


The valley of M'zab was designated as a World Heritage site because it meets three of the selection criteria:

1) Criterion (ii): represent a human settlement of important interchange of human values by their original architecture, town-planning, or landscape design in the cultural area of the central desert. This settlement affected on Arab architecture and town-planning for a long time.

2) Criterion (iii): the M'zab Valley is an exceptional testimony of the Ibadis culture with its urban ensembles consisting of ksour, cemetery, palm grove, and the ingenious system for capture and distribution of water.

3) Criterion (v): an outstanding example of a traditional human settlement representative of human interaction with the desert environment and Islamic Ibadis culture [11].

M'zab Valley. The M'zab Valley is a natural region of deep, narrow oasis in the desert, with five ksour (plural Arabian name of fortified cities, the singular of it is ksar) known as the Pentapolis (from Greek "penta" means "five" and "polis" means "city"). Five cities of pentapolis: Ghardaia, Melika, Beni Isguen, Bounoura, and El Atteuf are spread along the valley of length over $10 \mathrm{~km}$. They gathered in agglomeration for political, commercial and military reasons and were created between 1013 and 1355 by the Ibadites for communal living, within an egalitarian social structure that respects the privacy of the family. All ksour of M'zab Valley are adapted to the environment perfectly (Fig. 3) [12].

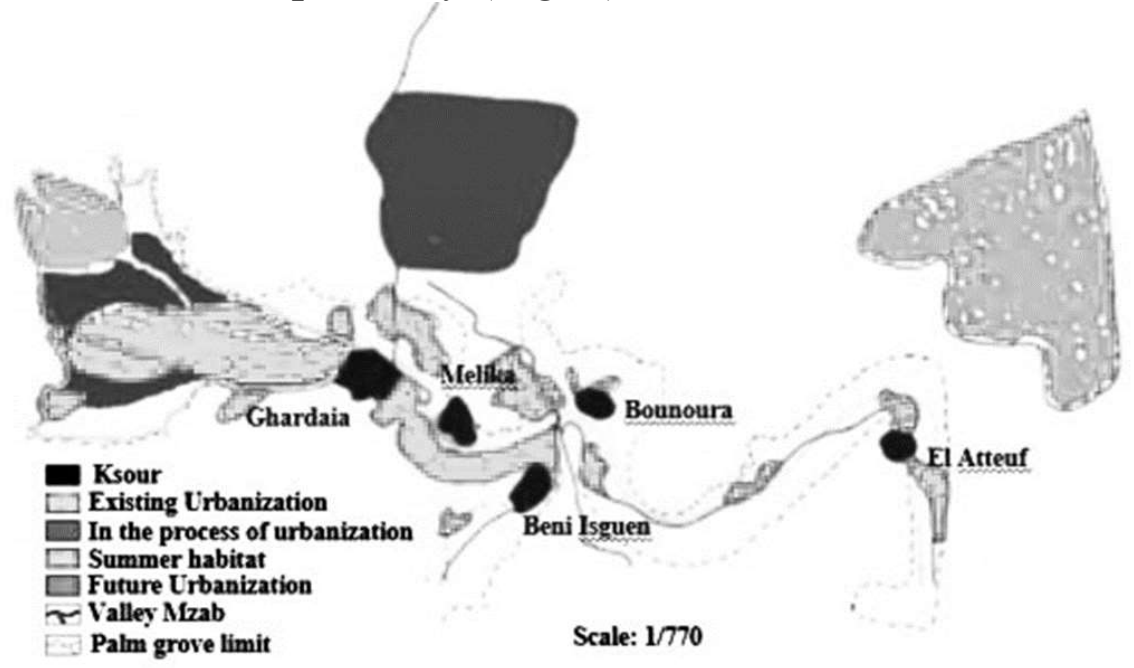

Fig 3: The location of five ksour "the pentapolis".

(Source: Urbanisation de la vallée du M'zab et mitage de la

palmeraie de Ghardaïa, http://journals.openedition.org/belgeo/24469, modified by Author.)

The Mozabites are the inhabitants of valley (360,000 inhabitants). They are ethnic of the Amazigh large tribe speaking Mozabite (Tumzabt), which is a branch of 
the Zenati group of Berber languages (Tamazight) and Maghreb Arabic. Initially the Mozabites were Christians but after the Arab Muslim conquest of the Maghreb between the 7th-8th centuries, they convert to Islam. The Rostemid dynasty, of the Ibadi doctrine, founded the town of Tahart in 761. After it fell in 909, the Ibadites took refuge in the city of Sedrata. After the destruction of their city Sedrata (the 11th century) which was not safe and lay in an open desert, the Ibadites had gone in search of a truly inviolable shelter to practice their religion in peace that was the M'zab valley. They built the five cities there starting by El Atteuf in 1012, Bou Noura 1048, Ghardaia1053, Melika 1124, to Beni Izguen 1347. In the Ottoman period, the populations of M'Zab maintained allegiance to Turkish authority. During this period, dissident factions from Ghardaïa founded two cities in the north of the valley, Guerrara, and Berriane.

When France Conquered Algeria in 1830, the M'zab was annexed to France in 1882 and it returned to Algerian autochthonous govern in 1962. Upon its national independence, Ghardaia became the capital of the valley of M'zab, and during a new administrative division in 1984 became the 47th Province of Algeria [12-15].

The M'zab Valley is located on the South part of the Algerian Sahara, $600 \mathrm{~km}$ south of Algiers, in the Province of Ghardaiia, exactly between $33^{\circ}$ and $31^{\circ} 15^{\prime}$ north latitude and between $2^{\circ} 30^{\prime}$ and $5^{\circ}$ east longitude. This region extends over a deserted, dry and arid valley that named "chebka of M'zab". Several provinces bound the territory of Ghardaiia: Laghouat in the North, Tamanrasset in the South, Ouaragla in the East, Bayedh in the West, Djelfa in the North-East and Adrar in the SouthWest (Fig. 4) [15-16].

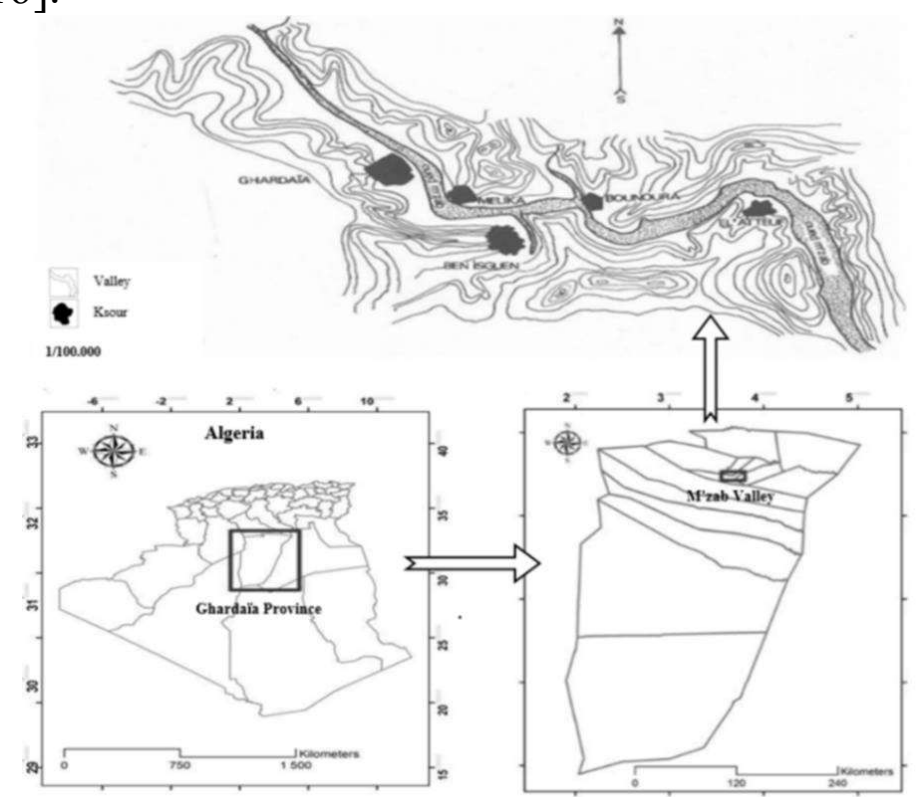

Fig 4: The location geographic of the M'zab Valley. (Source: Decoupage Administratif de l'Algerie, http://decoupageadministratifalgerie.blogspot.com/2014/10/cartegeographiqueGHARDAIA.html, modified by Author) 
The Saharan climate is characterized by scorching hot summers and mild winters. The region is marked by a large amplitude between day and night temperature, summer and winter, varying from $0^{\circ} \mathrm{C}$ to $46^{\circ} \mathrm{C}$ min. The average temperature of January here is for about $10^{\circ} \mathrm{C}$, of July - for about $33^{\circ} \mathrm{C}$ with minimum of $0^{\circ} \mathrm{C}$ and maximum of $46 \mathrm{C}$. There are 10 days of rain annually on average. Annual quantity of precipitations is $50-60 \mathrm{~mm}$ with minimum of $18 \mathrm{~mm}$ and maximum of $120.5 \mathrm{~mm}$. The winds are mostly coming from North-West direction in the winter and from North-East in the summer, the Sand winds are usually coming from South-West [15].

Mozabite Architecture and urban planning. The ksar is a Saharan agglomeration in where the Mozabites have already lived for a millennium. It reflects a well-defined social order and an image of coherence and rigor. The city develops according to a radio-concentric scheme. The creation of ksar began with the first nucleus that are characterized by a dense and compact urban fabric. The mosque was the first building constructed at the top of the summit, and then the dwellings are gradually wrapped around it downward in a contiguous way to reduce the areas exposed to the sun. Here also exist some facilities such as a market or cemeteries functionally distributed in urban fabric (Fig. 5).

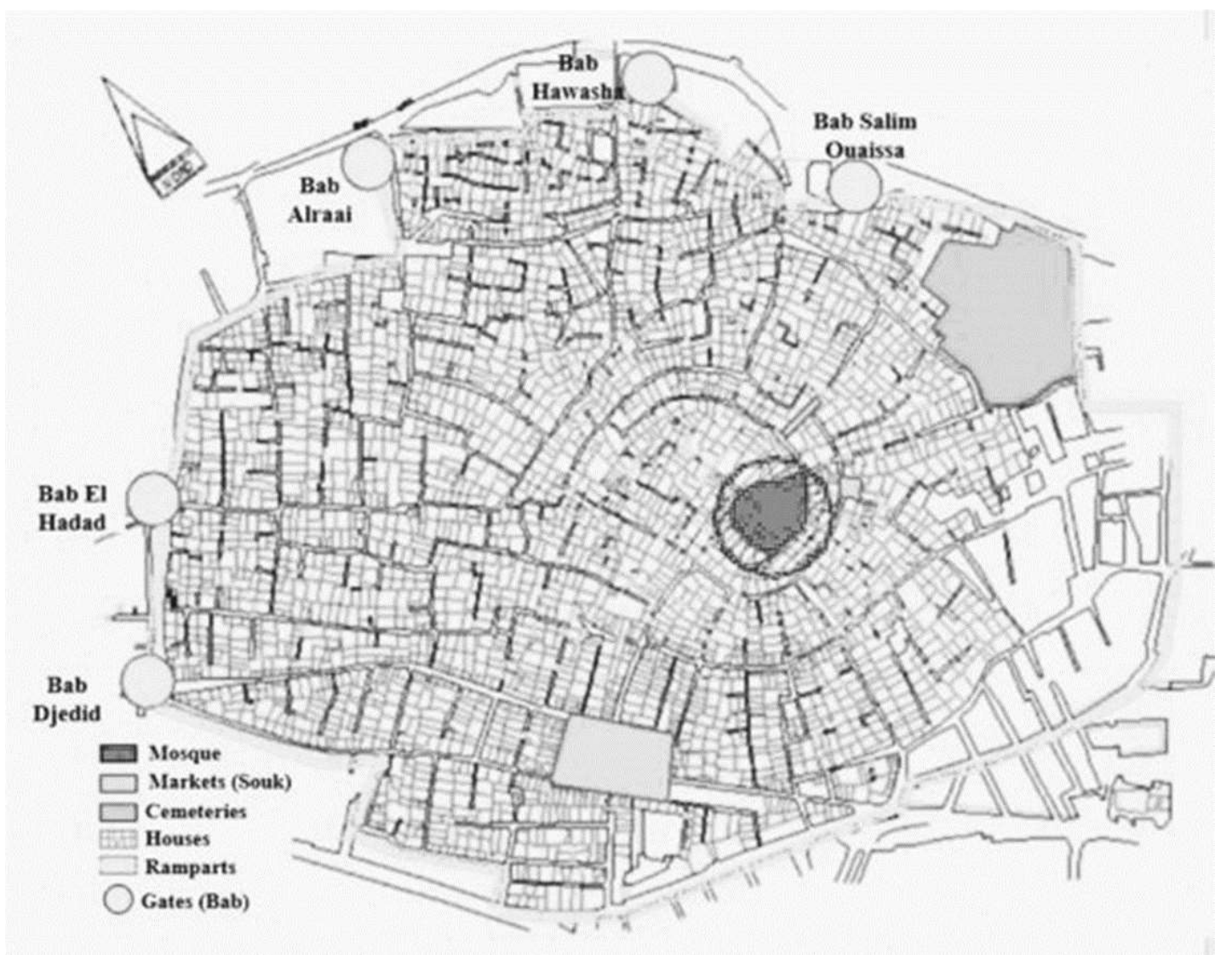

Fig 5. Urban planning of the M'zab Valley's ksar Ghardaia.

(Source: Series of Ksour Ghardaia: Ksar Ghardaia " Taghardait ", modified by Author). 
A complex road grid characterizes the ksar assuring the movement inside. The streets of the ksar are narrow and winding, often winding in the form of mazes, following the topography of the ground to create shade and reduce the degree of steepness. Some of them are covered with roofs, and some are impasses or blocked alleys connected to houses and considered as semi-private space. This feature creating an inner space of the settlement adapted to the climate in summer and winter by obtaining more shade and protection from winds and sand storms, and for defensive purposes as well. There are three types of roads inside the ksar: principal roads, secondary roads and impasses (see Fig. 5) [13, 17-19].

Main structural elements of such fortified city urban structure are as follows:

Mosque: the mosque is the strategic element in the city around which the life is organized. It is the central and spiritual nucleus of a ksar, occupying the highest position by virtue of its religious functions, which requires sanctity, and also plays the role of the meeting room, pantry, and defensive centre for the city.

Defensive system walls, gates, and towers: the ksour of M'zab have been planned basing on the Islamic city's principles in terms of location, they are protected by ramparts of $4-5 \mathrm{~m}$ high. The ramparts have gates along their entire length. The gate in the ksar is an essential object because it represents for the inhabitants both security and the link with the outside. It connects the city with the surrounding territory: palm grove, valley, and communication route. The rampart and its gates materialize the limit, the protection, and the threshold of the ksar.

Souk (Market): is usually located near to city's gates to facilitate foreign trade exchanges and control entry and exit to and from the ksar.

Houses: are situated around the mosque, they have different and unequal geometric shapes. Their height, size, and internal space are designed according to religious, social, and climatic criteria.

Cemeteries: are located outside the walls and constitute a barrier to the urban extension, it extends over vast areas, containing covered funeral chapels and others to the open air, where religious rituals are held during funerals and are used to recite the Qur'an and distribute alms.

Oasis and irrigation system: the palm oasis are located near the city and contain many traditional irrigation facilities for storing rainwater in dams to supply the subterranean layer as well as drainage and distribution of the water in an accurate and wise manner within the orchards by the terrestrial and water channels. These oases developed to be a dwelling in summer, many houses were built there to live in throughout the summer and to benefit more from its refreshing air, the shades of the palm trees, and the availability of freshwater [6, 15, 19-21]. 
The methods of harmonization with environment and climate adaptation techniques of the ksar urban structure. Each ksar is installed on a rocky peak overlooking the valley. On the one hand, this situation offers a "radiant" view of a defensive interest. On the other hand, its location kept away from land and water allows the preservation of water resources and fertile soils for agricultural activity. The ksar is planned in the form of a radioconcentric grouping. The compact urban form of the ksar is designed in a spirit of economy of land as well as to protect itself from the prevailing winds and the winds of sand. The houses of the ksar are placed one against the other with a total occupation of the plot. This conception of urban space leads to an introversion of the inhabited space and makes the dwelling protected from any insolation or noise and climatic nuisance effect.

The streets, alleys and dead ends are governed by a spatial hierarchy; from public to semi-public then to the private areas in front of the entrance to the houses. They also have a hierarchy of natural lighting, by the shade they give and their privacy. This effect creates a psychological barrier to strangers to warn them that they are not good to come into this space. The alleys are narrow and winding, creating shade and minimizing exposure to solar radiation. The relationship between the height of the buildings and the width of the street or lane further strengthens this principle. The oases of palm trees surrounding the city are an essential part of the ksar making it possible to survive in severe natural environment of desert. [22]

Conclusions. To summarize, the architecture Mozabite showed that the concept of sustainability was historically existed and layered spontaneously in the valley of M'zab for more than a millennium. Although the limited resources, however, the Mozabite was able to provide livelihoods and design a liveable atmosphere with optimal use of climatic conditions, especially solar energy, and adapt to the environment. Analysing the ability of ancient traditional settlements historically existing in special natural environment (such as the ksour of M'zab Valley in the desert) to preserve their ancient way of living in modern time it could be noted the primary need to preserve not only urban structure of such settlements but also traditional natural environment and local resources around them. To synthetize, we can assume that in contemporary world it is not possible to preserve traditional way of living without continuous harmonisation of historic settlements with its natural environment.

\section{References}

1. André Coyne. (1879). Le Mzab. Typographie A. Jourdan. (in French).

2. Amat Charles. (1888). Le M'Zab Et Les M'Zabites. Challamel. (in French).

3. Marcel Morand. (1903). Les kanouns du Mzab. Typographie A. Jourdan. (in French). 
4. Marcel Mercier. (1922). La civilisation urbaine au Mzab. Emile Pfister. (in French).

5. Goichon, M. (1927). La Vie Feminine au Mzab: Etude de Sociologie Musulmane. Librairie Orientaliste Paul Geuthner. (in French).

6. André Ravereau. (2003). Le Mzab, une leçon d'architecture. Actes SudSindbad. (in French).

7. André Ravereau. (2003). L'atelier du désert. PARENTHÈSES. (in French).

8. Manuelle Roche. (2003). Le M'Zab cites millenaire du Sahara. ETUDES \&amp, COMMUNICATIONS EDITIONS. (in French).

9. Brahim Benyoucef. (2018). Le M'zab: Regards d'urbanisme et de sociologie. Librinova. (in French).

10. Algeria, One World Nations Online. (in English). https://www.nationsonline.org/oneworld/algeria.htm

11. UNESCO official Site (in English). https://whc.unesco.org/en/statesparties/dz

12. OPVM. The tangible and intangible heritage of the province Ghargaia, Ed El Alamla, Ghardaïa, Algeria. (in English). http://www.opvm.dz

13. Djelloul Zenati. (2018). Urban Development in the Heritage Cities, Wadi Mazab. KnE Engineering, 3(4), 405-424. DOI: 10.18502/keg.v3i4.2183 (in English).

14. Alport, E. A. (1954). The M'zab. The Journal of the Royal Anthropological Institute of Great Britain and Ireland, 84 (1/2), 34-44. (in English).

15. THOMAS Schmitt. (2009). Protection of cultural heritage and socio-cultural transformation in the M'Zab valley. A world heritage site in Algeria. In: The Maghreb countries. Contributions from German Human Geography. Herbert Popp. (in English).

16. ADAD, M. C. and REDJEM, A. (2012). Production of habitat in new ksour, symbiosis between State intervention and Community action: the case of Ksar Tafilelt in the M'zab valley. Perspectives \& Societies Review, 3, 124-148. (in English).

17. Imen Bensalah, Badreddine Yousfi, Nadjat Menaa and Zohir Bougattoucha. (17 July 2018). Urbanisation de la vallée du M'zab et mitage de la palmeraie de Ghardaïa (Algérie): un patrimoine oasien menacé. Belgeo [online]. (in French). https://journals.openedition.org/belgeo/24469.

https://doi.org/10.4000/belgeo.24469

18. Josse Raymond. (1970). Croissance urbaine au Sahara: Ghardaïa. Les Cahiers d'Outre-Mer, January-March, 46-72. (in French). https://doi.org/10.3406/caoum.1970.2536 https://www.persee.fr/doc/caoum_03735834 1970 num $23 \quad 89 \quad 2536$

19. Baghbagha Abdel Aziz, Baba Najjar Yunus. Ksar Ghardaia. Ghardaïa, Algeria (in Arabian). 
http://www.opvm.dz/19 Brochures/171_Ksar_de_Ghardaia__Arabe_/d

20. Ramadan Kamal, Hamo Abdullah Al-Hajj, Baba Najjar Yunus. Custom in traditional construction valley M'zab. Ghardaïa, Algeria (in Arabian). http://www.opvm.dz/en/19 Brochures/34 Custom in traditional construction valle y_M\%E2\%80\%99zab (Arab)/d

21. Lalot Bahmad, Zabab Khudairhe, Baba Najjar Yunus. (2014). The traditional house: Architecture and custom in the protected sector of the M'zab Valley. Ghardaïa, Algeria. (in Arabian).

http://www.opvm.dz/en/19_Brochures/110 traditional_house_(arabic_)/d

22. Nora GUELIANE, Karima HADDOUCHE. (2015). Revisit a Millennium heritage: energy performances of traditional Mozabite Habitat. International Seminar on Climate and Energy Engineering, SIGCLE, November 9, 10 and 11. Constantine, Algeria. (in English).

Аннотация

Ноурэль хоуда Резиг, аспирантка кафедры Основ архитектуры и архитектурного проектирования, Киевский национальный университет строительства и архитектуры.

Древние традиционные поселения в Алжире: Пентаполис долины М'заб.

Статья посвящена обзору древних традиционных поселений Алжира, а именно, специфического градостроительного феномена архитектуры долины М'заб, состоящего из пяти сохранившихся исторических поселений, так называемых ксуров, собранных в агломерацию долины М'заб (так называемый Пентаполис) в оазисе пустыни Сахара. Проанализированы традиционная планировочная структура и архитектура ксуров на градостроительном (макро) уровне. Особое внимание уделено техникам климатической адаптации застройки поселений к суровым природным условиям пустыни Сахара. Пентаполис долины М'заб является уникальным примером агломерации, где люди проживают сохраняя традиции и уже более тысячи лет используя ту же самую городскую инфраструктуру и застройку. С этой точки зрения Пентаполис можно рассматривать в качестве уникального примера для изучения процесса адаптации (гармонизации) сложившегося веками традиционного способа жизни к условиям современности посредством существования в согласии с окружающей средой.

Ключевые слова: Долина М'заб; архитектура Мозабитов; Пентаполис ксур; традиционное поселение; Алжирская пустыня; памятники ЮНЕСКО. 
Анотація

Ноурель хоуда Резіг, аспірантка кафедри Основ архітектури i архітектурного проектування, Київський національний університет будівництва і архітектури.

Давні традиційні поселення в Алжирі: Пентаполіс долини М'заб.

Стаття присвячена огляду архітектурних пам'яток Алжиру, що входять до списків світового надбання ЮНЕСКО, в першу чергу це традиційні поселення долини М'заб. На початку роботи наведено основні історичні, культурні, мовні та кліматичні реалії Алжиру, в табличній формі представлено повний список архітектурних пам'яток ЮНЕСКО країни з їх територіальним розташуванням (мапа) та мотиваціями внесення до Всесвітнього списку культурного надбання. Основну увагу в роботі приділено урбаністиці і архітектурі тисячорічних відокремлених поселень долини М'заб, що включає в себе агломерацію (так званий Пентаполіс) 3 п'яти автономних замкнутих стінами i оточених пальмовими плантаціями укріплених поселень (так званих ксурів), розташованих в центрі країни, в оазисі пустелі Сахара. Планування кожного 3 ксурів характеризується сталою радіальною урбаністичною структурою та наявністю в тканині поселення визначеного набору територіально фіксованих функціональних складових: мечеті, ринка, кладовища, житлових будинків, критих вулиць, міських стін, брам та укріплень. В статті наведено короткий історичний огляд публікацій щодо архітектури ксурів долини М'Заб (переважно на французькій мові), окреслено історичні умови формування i сучасні реалії їх існування. Архітектуру поселень проаналізовано на макрорівні, як композицію цілого урбаністичного утворення. Окреслені особливості екологічного та кліматичного пристосування урбаністичної структури поселення до суворих навколишніх умов. Особливу увагу приділено формулюванню традиційних прийомів організації забудови. Висновки роботи акцентують увагу на історичній екологічності та ситуативній розумності організації традиційних поселень долини М’Заб в Алжирі, констатуючи можливість збереження традиційного життя в Пентаполисі лише за умови продовження гармонізації урбаністичної складової долини М'заб 3 навколишнім середовищем, що фіксує напрямок для подальших досліджень цієї теми.

Ключові слова: Долина М'заб; архітектура Мозабитів; Пентаполіс; ксур; традиційне поселення; Алжирська пустеля; пам’ятки ЮНЕСКО. 